\title{
Chinese Corporate Law Developments and Go-Global Policy
}

\author{
Emanuele C. Francia ${ }^{1,2}$ \\ ${ }^{1}$ The Law School of Tsinghua University, Beijing, China \\ ${ }^{2}$ CAU-China Agricultural University, Beijing, China \\ Email: ecf76italy@hotmail.com, manu.francia@cau.edu.cn
}

How to cite this paper: Francia, E. C. (2020). Chinese Corporate Law Developments and Go-Global Policy. Beijing Law Review, 11, 184-202.

https://doi.org/10.4236/blr.2020.111013

Received: November 14, 2019

Accepted: March 3, 2020

Published: March 6, 2020

Copyright (c) 2020 by author(s) and Scientific Research Publishing Inc. This work is licensed under the Creative Commons Attribution International License (CC BY 4.0).

http://creativecommons.org/licenses/by/4.0/

\begin{abstract}
While in many countries we observed a privatization of many businesses, China adopted a different personal way called 'corporatization', i.e. "entails restructuring state enterprises, adopting the corporate form, and instituting stock ownership and trading without necessarily relinquishing the state's controlling interest in the means of production" (Art \& Gu, 1995). It worth mentioning the particular efforts to improve the economy which led to thirty years double-digit GDP growth and continuous growth at a high 6\% - 7\% still today ${ }^{1}$. Many changes took place and many new regulations have been introduced to achieve such remarkable results, in particular, the "enormous effort at reforming state enterprises" is a never-ending activity and in fact nowadays there is much discussion on how to keep improving those firms' efficiency, effectiveness and increase performance. Although nobody knows how China will look like in twenty years, as inquired by (Ramo, 2014) or further future, we can guess that it will fundamentally contribute to the worldwide economy and its international business might represent a paramount model for other economies. How the modernization pro-market trend can be advanced if at the same time the Party role keeps being crucial in directing business? The answer we think stands in the unique idea of "Socialist modernization". Some also question how such policies can cohere with capital
\end{abstract}

\footnotetext{
${ }^{1}$ Source: Worldbank website

https://data.worldbank.org/indicator/NY.GDP.MKTP.KD.ZG?locations=CN. And "Stable Chinese economic growth major driving force in global recovery.

Since opening-up 30 years ago, China's economy has become more and more important to the world economy. According to World Bank data, China's GDP rose from 1.2 percent of the world's GDP in 1979 to 9.3 percent in 2010. That figure rose to 11.9 percent in 2015 with an average growth of 0.5 percent during the $12^{\text {th }}$ Five-Year Plan period. China makes up 14.8 percent of the world's economy, behind the United States which accounts for almost a quarter. Japan and India represent 5.6 percent, and 2.8 percent of the world's economy respectively" (The State Council, People's Republic of China),
}

http://english.www.gov.cn/news/top news/2017/01/14/content 281475541536155.htm). 
market that is becoming more international. In our view, it is especially the increasing international exposure that will lead to Corporate Governance improvement in China and will adjust possible distortions. In order to compete internationally, the best practices must lead. We observed how great advances in China's economy have been paired and supported by amazing social and legal improvements, most of them related to the Internationalization. In fact four periods and policies marked the success of China of the last fifty years, all involving an always increasing Chinese international exposure: the "Open door policy", the WTO accession, the Beijing Consensus, the Belt and Road Initiative and China International M\&A activities. China President Xi Jinping confirmed the national goal several times, the latest at the inaugural China International Expo in November $2018^{2}$ claiming China's goal to "deepen international trade and economic cooperation, promote Belt and Road Construction and advance economic globalization". Both, in Chinese private corporations and State-owned enterprises the Party organizations are established to "implement the Party's principles and policies, guide and oversee" to implement the big picture of the Socialism with Chinese characteristics.

\section{Keywords}

Corporate Law, Corporate Governance, Convergence, International Business, M \& A, Open-Door Policy, WTO Accession, BRI (Belt And Road Initiative)

Homo sum, humani nihil a me alienum puto $I$ am human, I consider nothing human alien to me

(Terence, $165 B C$ )

\section{Paper's Intro, Key-Questions and Scope}

$$
\begin{array}{r}
\pi \dot{v} v \alpha \alpha \dot{\rho} \mathcal{\imath}(\text { panta rhei) "everything is changing" } \\
\text { (Heraclitus, C. } 535-\text { C. } 475 \text { BCE) }
\end{array}
$$

\section{Introduction: The Importance of the Corporate Law Frame}

What "cockpit" do we want to adopt to drive business?

Rotman in 2010 inquires whether we should see corporations as profit generators which ultimate goal is to maximize shareholders wealth or conversely underline the importance of multiple stakeholders which companies should take care of.

He also notices how (ironically) the debate about those questions was born long ago with Adolf Berle of Columbia University and Dodd at Harvard.

Almost one hundred years later such fundamental issue is still open and as he notices "those questions must be addressed before the application of corporate

\footnotetext{
2“The Expo is not an extraordinary event, but marks China's new round of advancing high-level opening up as well as the country's taking significant steps to open its market to the rest of the world" China Daily, November $5^{\text {th }}, 2018$.
} 
management's duties can be meaningful considered".

The trigger of this article has been the work done for several years in different countries as a business consultant and lawyer, trying to improve companies' performance by changing the company's organization and structure, some time to refocus more on customers and marketing. The project mechanic has almost always been the same. It starts with an industry analysis in order to identify the most successful competitors (Benchmarking). An accurate analysis of their operations can tell us what best practices deserve attention. A consequent internal analysis of the company tells what commonalities and differences there are. The last step is to pick the best practices which best fit the company's need and capabilities. Despite the success of many projects, From some failure we can learn a great basic lesson: the fish stinks from the head. This means that if the company does not have-a-proper powers and goals setting structure there is no chance to succeed as best practices' importation activity will somewhere get stuck and neither real impact on a better system nor better performance will be achieved. Why does that happen? The conclusion is that staying at the operations level is not enough to facilitate the process. Only by moving upward to the corporate law and governance level, we could observe and sometimes adjust the structure loopholes and then go down again to facilitate the implementation of best practice at the business level. Therefore this paper, as academic work, intends to start from the top, analyzing the corporate structure and rules first. The following step will be to drill down to corporate governance ${ }^{3}$ and business operation.

In sum, until we are not capable to give an ultimate answer to the questions such as what the purpose of corporations is, what the directors and managers duties are and towards whom, we have no clear orientation and cannot even attempt to change and lead management and operations to improve company's performance. In order to avoid the negative effect of externalities or "tragedy of the commons" where individuals will benefit from resources to the detriment of others and society ${ }^{4}$, as said by many voices and recalled in the documentary The Corporation (Bakan, 2003): "it is first a matter of vision" and mission definition.

In this paper the affirmed view is that we are nowadays assisting to fast developments in the corporate law and governance principles in many jurisdictions and in particular towards an orientation to incorporate more social goals. As a paradigm we take here the Chinese frame as it has historically given much importance to stakeholders and differ from profit maximization objectives. We dare to affirm we can see a convergence pattern in corporate law and China is bringing a determinant contribution to such phenomenon. It seems in fact that perhaps in different countries corporate law and governance tends now to converge to common (social) goals and practices. Very differently from the previous approach of convergence which assumed the U.S. model to prevail ("end of history" stated by Hansmann and Kraakman (Hansmann, 2006; Hansmann \&

${ }^{3}$ See Minichelli, 2014 for an analysis current corporate governance state of the art.

4"Individuals use up resources shared by many to benefit themselves"

(https://corporatefinanceinstitute.com/resources/knowledge/economics/tragedy-of-the-commons/). 
Kraakman, 1997, 2012), nowadays we are observing new trends towards a new point. The U.S. business orientation focusing solely on the maximization of profit has been widely criticized and it seems moving now towards higher care of broad stakeholders' interests (e.g. society and the environment) and the achievement of non-financial goals (Freeman, 1984; Blair, 1995, 2012; Stout, 2012; Blair \& Stout, 1999). At the same time in the Chinese system, there is a broad debate on the option to move exactly to the other direction towards more attention on companies' performance in order to make firms more effective and efficient. However, Chinese companies still maintain their historical broad role and multiple social goals. How does this flow move nationally and internationally?

The Main questions to investigate will be the following:

- What is the Socialism with Chinese characteristics?

- What is the Chinese Go-global policy?

- What direction the reforms of the Chinese corporate law and governance rules are taking?

- What principles lead the business in China?

The literature review includes Corporate Law, national policies, Corporate Governance, and Management in China.

\section{China reform Process and Internationalization}

\subsection{China: "Socialism with Chinese Characteristics"}

The Chinese business economy is deeply influenced by the social structure and the political system as well as by the peculiar country's history and set of values (Sisci, 2004-2006). The so called "socialism with Chinese characteristics" represents a unicum in the world ${ }^{6}$. Some of the main dilemmas the legislators and the decision makers constantly face are the choice between market $\mathrm{v}$. planned economy, decentralization $\mathrm{v}$ (re)centralization, contractual party autonomy ${ }^{7}$ v. state control and between imported rules v. self-produced laws (Fang, 1995). A special place in China has always been occupied by the planned economy. In the so called "Golden Age (by Marie-Claire Bergere for the period 1916-1927) a sort of "spontaneous modernization" is the side of the coin represented by the weakening of the state authority and with the "proliferation of commercial transactions". Given the above, and despite the first 1904 Company law was designed to support such development, "corporate form remained rare even during Chinese capitalism's "golden age" and despite conscientious efforts to improve the Gongsili of 1904" (Kirby, 1995). Even China's more "capitalistic"

\footnotetext{
${ }^{5}$ Definition of unicum: a thing unique in its kind. Especially: a sole existing exemplar (as of a writing). https://www.merriam-webster.com/dictionary/unicum.

${ }^{6}$ For a comparative analysis of corporate law and its impact on different systems see Ventoruzzo (2007); Ventoruzzo et al. (2015).

${ }^{7}$ For the structure of contract law in China see Mo Zhang (2006).

${ }^{8}$ Also presented by Peeremboom (2008).

${ }^{9}$ For a clear explanation of the classic capitalistic approach, German model and UK-U.S. see (Martufi, 1998).
} 
period appeared different from most of other countries", "with its own organizational structures and values rooted in networks of family and regional ties", resisted the corporate form and the development of private initiatives so that the biggest portion of the economy has since ever been led by state-controlled firms.

In addition, the unique Nationalization of the Corporation in the period 1929-45 used "law as a one vehicle in promoting state ascendancy over private enterprises" (Kirby, 1995). While in many countries we assisted to a privatization $^{10}$ of many businesses, China adopted a different personal way called corporatization, i.e. "entails restructuring state enterprises, adopting the corporate form, and instituting stock ownership and trading without necessarily relinquishing the state's controlling interest in the means of production" (Art \& Gu, 1995). It started as a "self-initiated experiment by a group of small- scale state enterprises. Later it became a limited experiment under the control of the government, and finally was allowed to spread to the entire society" (Fang, 1995).

\subsubsection{The Law Principles}

It worth mentioning the particular efforts to improve the economy which led to thirty double-digit GDP growth and steady growth at a high $6 \%-7 \%$ still today. Many changes took place and many new regulations have been introduced to achieve such remarkable results, in particular the "enormous effort at reforming state enterprises" is a never ending activity and in fact nowadays there is much discussion on how to keep improving those firms' efficiency, effectiveness and increase performance ${ }^{11}$. Although nobody knows how China will look like in twenty years, as inquired by Ramo $(2014)^{12}$ or further future, we can guess that it will fundamentally contribute to the worldwide economy and its international business might represent a paramount model for other economies.

How the modernization pro-market trend can be advanced if at the same time the Party role keeps being crucial in directing business? The answer we think stands in the unique idea of "Socialist modernization" and its law developments (Yu, 2010). As mentioned above China keeps a different social model from most western economies and the Party and the idea of "Socialist market economy" oppose the "bourgeois liberalization". In that, SOEs as public ownership play a fundamental role, "although different forms of corporate ownership can develop

\footnotetext{
${ }^{10}$ Especially in formerly communist nations of Eastern Europe but also in other economies where the state kept for a longtime a relevant control in several industries. For instance, the energy sector in Italy was privatized in the 1990s.

${ }^{11}$ One of the main problems still existing of large SOEs is summed-up for example in the "popular phrase "Yi gu du da" or "entrenched share gamble big" reflects the well-grounded belief that controlling shareholders often act in ways that severely harm the interests of the minority shareholders" (Kister, 2006).

${ }^{12}$ "It's tempting to think about what destination China might reach in 20 years. Will it be a seething pot of nationalist hate? A rich, super-large Singapore, warlike only in the board room? The common conceit of most non-Chinese policy planners is that in 20 years China will be a "near peer" power, bumping up against the United States in terms of economic and possibly military might. Thus, this logic runs, the next 20 years must be devoted to either engaging China to shape its rise or working to contain the country so it doesn't acquire more power than the current global power leaders. But the fact is that no one knows what China will look like in 20 years (Ramo, 2014).
} 
side by side" (ACGA, 2018 reciting the Preamble of the new Constitution, 2017). The CPC "shall be firm in consolidating and developing the public sector" and provide the guidelines to SOEs to implement the national policy. At the same time it should keep a leading role for "guiding the development of the non-public sector".

The Chinese Constitution of the CPC Art. 32 defines the primary-level Party organization as the "political core" of a state-owned enterprise (ACGA, 2018). In Art.33 Party members or committees shall "keep in mind the big picture, ensure the implementation of Party policies, and discuss and decide on major issues of their enterprise"13. Also in Chinese private corporations the Party organizations must be established to "implement the Party's principles and policies, guide and oversee". Both types of corporations "shall provide the Party organization with necessary facilities for its activities" (Art. 19 China Company Law, 2006 ${ }^{14}$ ). By the end of 2016, over $90 \%$ of the public enterprises (around 190 thousand) and almost 70\% of non-public firms (around 1.85 million) have established CPC organizations.

What do those Party organizations exactly do and how their work interacts with the other CG bodies? Theoretically they "participate in the governance of enterprises" but without "directly meddling in their management and operational decision-making" (ACGA, 2018). At a first sight, it could be seen as a compliance department of many western companies, entitled to make sure the company's activity abides by the law and "set the right direction", i.e. the socialist market economy and the national goals ${ }^{15}$. In addition, and this part might be widely contradictory with the general CG framework discussed so far, it could also decide on "major issues", the scope of which can represent a major deviation from the CG principle, introduces power overlapping and ambiguity. According to ACGA (2018) in this regard, three main functions can be seen:

1) Making the "Three Important, One Large" decisions ${ }^{16}$

2) "Double entry, cross offices"17

3) Overseeing the system of "Party supervising cadres" and "Party supervising talents"18.

\footnotetext{
${ }^{13}$ Constitution of the Communist Party of China, 2017.

${ }^{14}$ Company Law of the People's Republic of China (2005), Document No. Order of the President of the People's Republic of China No.42 Promulgation Date 2005-10-27 Effective Date 2006-01-01. Promulgation By the Standing Committee of the NPC. https://www.accaglobal.com/content/dam/acca/global/pdf/ChinaCompanyLaw2006.pdf ${ }^{15}$ "implementation of Party policy", "keep in mind the big picture", etc.

16“Appointment and dismissal of "important cadres", investment in "important projects" and the use of large amount of funds" (ACGA, 2018). Important decisions seem to require the pre-approval of Party committees.

${ }^{17}$ "Party committee members can also serve on either the board of directors or supervisory board, and be part of the executive team" (Id.). thus is supposed to help effective decision making, consistency and communication.

${ }^{18}$ "The Party carries out the induction, training, and development of national professional talent by the implementation of the "National Plan of Talent Development in Medium and Long Term (2010-2020)" (id.)
} 


\subsubsection{The State-Owned Enterprises Central Role}

In SOEs, which business objective and corporate purpose have since the beginning to serve national interest and implement national policies (Zhang, 2014), such rules and system do not raise particular concerns. On the contrary the move is seen as a new search of transparency and clear acknowledgment of the Party role ${ }^{19}$. In fact, President Xi Jinping made clear on several speeches that SOEs goal is to "integrate the Party's leadership into each part of corporate governance ${ }^{20}$, embed the Party organization of the enterprise into the corporate governance structure"21. He was also backed by the State Council circulars ${ }^{22}$ emphasizing the Party role within the CG SOEs frame (Tse Caleb, Yu, \& Tse, 2012). Therefore the formalization of Party organizations simply follows that direction and adds clarity to the governance. Although some worry that the businesses decision making process might in general turn to be less efficient (power overlaps and lack of coordination ${ }^{23}$ ), what is more debated, as said, is the role of Party organization especially within non-public firms. "People with pro-market views see them as a regressive and fear they will weaken the function of other governance entities" (ACGA, 2018), especially the role of the board of directors and its power to take effective business-oriented independent decisions. However, some counter voices see that as an opportunity to make business smoother and it may especially help foreign companies operating in $\mathrm{China}^{24}$. Qi Yu, deputy head of the Central Organization Department, for instance, said that "Party organization can help them understand China's policies in a timely manner, resolve labor disputes and provide positive energy for the companies' development" ( $19^{\text {th }}$ National Congress, October $\left.2017^{25}\right)$. Whether this is the best proper and effective way to achieve such results is a question mark. The European Chamber of Commerce, in fact, issued a statement in $2017^{26}$ arguing that no legal provision nor business efficiency principles require that and they worried such "additional layer of governance would have serious consequences for the Independent decision-making ability", in particular of JVs, and they foresee a risk of Party members interference in

\footnotetext{
${ }^{19}$ In "Interview: 'Moving Party committees in front of the curtain"”, John Law (IFC) sees that positively as a "move from behind the scenes to the front of the curtain" and Jenn-Hui Tan (Fidelity International) thinks it will favor the China capital markets development as increase transparency (ACGA, 2018).

${ }^{20}$ See Tomasic (2010).

21 "And specify and implement the legitimate standing of the Party organization in the corporate governance structure of the enterprise" (October $\left.11^{\text {th }}, 2016\right)$.

${ }^{22}$ Guiding Opinions on Further Improving the legal Person Governance Structure of State-owned Enterprises, No.36, 2017 and Notice on Forwarding the Plan of SASAC on Focusing on Capital Management and Advancing the Functional Transformation, No. 38, 2017.

${ }^{23}$ Including accountability and problems in pursuing inconsistent goals derived from the double roles ("double entry or cross office") which also reduce the relevance of some board committees (e.g. nomination) and the function of non-executive and independent directors.

${ }^{24}$ In the period 2011-2016 more than 50 thousand foreign companies registered in China introduced Party organizations (totally more than 100 thousand). And the same for foreign- funded firms in China (70\% of the total, i.e. 75 thousand firms).

${ }^{25}$ http://english.qstheory.cn/2018-02/11/c 1122395899.htm

${ }^{26}$ November $3^{\text {rd }}, 2017$.
} 
companies governance and operations ${ }^{27}$. Perhaps more clarity and accountability is still required to better define the role and the scope of Party organizations within both public, non-public, Chinese and foreign-invested firms (Mahony, 2015).

\subsection{China "Go-Global" Policy}

Some also "question how such policies can cohere with the capital market that is becoming more international". In our view, it is especially the increasing international exposure ${ }^{28}$ that will lead to corporate governance improvement in China and will adjust possible distortions. In order to compete internationally, the best practices must lead. We observed how great advances in China's economy have been paired and supported by amazing social and legal improvements, most of them related to the internationalization ${ }^{29}$. In fact, four periods and policies marked the success of China of the last fifty years, all involving an always increasing Chinese international exposure: the "Open door policy", the WTO accession, the Beijing Consensus, the Belt and Road Initiative and China International M\&A activities (Zhang, 2003). Recently China refocused its goals: "The real economy is the foundation of economic strength that makes China prosper. The Party's Report to the 19th CPC National Congress (the Report) states: "we must focus on the real economy" $(\mathrm{EY}, 2018)^{30}$.

\subsubsection{The "Open-Door Policy" and Further Advances}

The modern era of China started with Communist party shift "from strict adherence to socialist state ownership to modernization and economic reform" (Art \& Gu, 1995), and "the 1982 Constitution and 1986 general Principles of Civil Law further encouraged the growth of private economy".

The Open-door policy of Deng Xiaoping in 1978 helped China to benefit from foreign contributions in the wave to modernization and growth. The three Represents or the important thought of Three Represents, the guiding socio-political theory credited to Jiang Zemin ${ }^{31}$, together with the Scientific Out-

${ }^{27}$ In particular the German Chamber of Commerce declared "Should these attempts to influence foreign invested companies continue, it cannot be ruled out that German companies might retreat from the Chinese market or reconsider investment strategies" (November 24 ${ }^{\text {th }}, 2017$ ).

${ }^{28}$ See Ohmae (1998) and Stiglitz (2002-2007) for a deep analysis of globalization and international business interactions.

${ }^{29}$ UNCTAD data on China, http://www.unctad.org

30" According to EY (2018), the Made in China plan 2015 and the new goals set at the $19^{\text {th }}$ CPC National Congress about China international expansion can be summarized in:

"1- Promoting the real economy becomes a major consideration for overseas investment.

2- Going global strategy is deeply incorporated with BRI - infrastructure construction, trade and green field investment are the major cooperation models.

3- Chinese enterprises will further enhance globalization: international financing and supply chain will be the trend.

4 - The explosive growth in demand for international talents will determine the increment of overseas investment.

5 - Policies will be become more stable and predictable, promoting healthy and rapid growth of overseas investment".

${ }^{31}$ Which was ratified by the Communist Party of China at the Sixteenth Party Congress in 2002. 
${ }{ } o k^{32}$ and the idea of Harmonious society promoted by $\mathrm{Hu} \mathrm{Jintao}^{33}$, leads to economic and cultural development ${ }^{34}$ up to today Chinese dream of President Xi Jinping. He confirmed his ambitious plan in 2018 to "seeking progress while maintaining stability" and keep China on a "stable and healthy development track" ${ }^{35}$. At the same time, President Xi mentioned the main social goals China set, particularly "What we now face is the contradiction between unbalanced and inadequate development and the people's ever-growing needs for a better life"36.

A project to "realize the Chinese Dream of national rejuvenation" was already presented in 2012 dealing with an increasingly complex international economic situation and the deep need of reform "following the general guidelines of making steady progress, we have acted promptly to improve macro control and placed more emphasis on sustainable development" (Xi, 2014). It has been confirmed recently ${ }^{37}$. Such modernization process, with Chinese characteristics, is a multifacet and long committing plan to put in place deep reforms which and led to many achievements ${ }^{38}$ but also faced many difficulties ${ }^{39}$.

In order to advance, as a main driver to the economy, much attention has been devoted to SOEs development so that some scholars dare to argue that even the stock Exchange was created "first and foremost as a tool for SOE financing and reform, and not as a means of offering members of the general public a way to diversify their investment portfolios and hedge future risk" (Caragliano, 2009), 32"Advanced social productive forces, advanced culture, and the interests of the overwhelming majority".

${ }^{33}$ Ratified into the Communist Party of China's constitution at the $17^{\text {th }}$ Party Congress in October 2007.

${ }^{34}$ Consistent with the ideas of Mao Zedong and the pillars of Marxism-Leninism adapted to Socialism with Chinese characteristics.

${ }^{35} \mathrm{http}: / /$ chinaplus.cri.cn/news/china/9/20180731/164563.html

${ }^{36} \mathrm{Xi}$ made the remarks in a report to the $19^{\text {th }}$ National Congress of the Communist Party of China (CPC) at the Great Hall of the People in central Beijing, where he also discussed the long term plans "In the first stage from 2020 to 2035, the CPC will build on the foundation created by the moderately prosperous society with a further 15 years of hard work to see that socialist modernization is basically realized, according to the plan.

In the second stage from 2035 to the middle of the $21^{\text {st }}$ century, the CPC will, building on having basically achieved modernization, work hard for a further 15 years and develop China into a great modern socialist country that is prosperous, strong, democratic, culturally advanced, harmonious, and beautiful, according to the plan". http://chinaplus.cri.cn/news/china/9/20171018/40716.html.

${ }^{37}$ October 18, 2017, Xi Jinping, at the $18^{\text {th }}$ Central Committee of the Communist Party of China, $19^{\text {th }}$ National Congress. http://english.jschina.com.cn/special/36190/201711/t20171105 4806508.shtml.

38“We have made major breakthroughs in deepening reform. We have taken comprehensive steps to deepen reform swiftly but steadily, and worked with resolve to remove institutional barriers in all areas. We have taken moves across the board, achieved breakthroughs in many areas, and made further progress in reform. We have pursued reform in a more systematic, holistic, and coordinated way, increasing its coverage and depth. Thanks to the launch of over 1500 reform measures, breakthroughs have been made in key areas, and general frameworks for reform have been established in major fields. The system of socialism with Chinese characteristics has been further improved, with notable progress made in modernizing China's system and capacity for governance". Id.

39“'Outside China, we have been confronted with sluggish global economic recovery, frequent outbreaks of regional conflicts and disturbances, and intensifying global issues. At home, we have encountered profound changes as China has entered a new normal in economic development. We have upheld the underlying principle of pursuing progress while ensuring stability, risen to challenges, pioneered and pushed ahead, and made historic achievements in reform, opening up, and socialist modernization". Id. 
although channeling the "massive private savings of Chinese citizens into productive venture" (Art \& Gu, 1995) can also be seen as a purpose of the creation of capital markets and the Corporatization process. The difficulties the SOEs faced and still face today, work as one of the main motivators for the architecture of reforms.

\subsubsection{The WTO Accession and Beijing Consensus}

It continued with the WTO accession in 2001. As stated by Corvino ${ }^{40}$ (2005) "No country acceding WTO prior than China had to undertake such unparalleled economic, legal and political change. China's accession to WTO is somehow a unique process (Peter, Chang, 2003). It does not go only on how long is the schedule of commitments (the longest ever ...), or the number of laws and regulations amended or still to be amended for complying with such commitments (it seems thousands ...). Indeed, WTO accession acted as a lever for economic and legal reform by locking the road to reforms and making it irrevocable. In addition to causing liberalization of China's trading system, Chinese leadership sponsored through WTO accession the commencement of wide and profound legal reform, which will probably result in weakened control of the Communist Party on both the economic trends and on the growing civil society. China understood what accession would ensue in terms of domestic policies as well. If risks have been taken, this means chances have been deemed greater than challenges". And continues: "no country has endured as lengthy an accession process to the GATT/WTO as China, nor has any country acceding to the WTO been asked to take on as many concessions as the price for admission ${ }^{41 "}$.

Consistently with this pattern of generating mutual benefits for China and the international context, the Beijing consensus represents China's unique way to develop internationally and establish long-lasting mutual profitable relationships with and in other countries. As affirmed by (Ramo, 2004) "It replaces the widely-discredited Washington Consensus, an economic theory made famous in the 1990s for its prescriptive, Washington-knows-best approach to telling other nations how to run themselves. The Washington Consensus was a hallmark of the end of history arrogance; it left a trail of destroyed economies and bad feelings around the globe. China's new development approach is driven by a desire to ${ }^{40}$ Stefano Corvino has been an attorney at law active in Beijing, China from 2002-2015. Ful document not available.

${ }^{41}$ Generally speaking, the WTO accession process formally begins when a country informs the WTO Director-General of its desire to join. The WTO General Council then forms a "working party" of members to examine the application. After basic principles and policies have been resolved with the working party, individual WTO members enter into bilateral negotiations with the applicant country over the specific undertakings that the applicant will agree to as a condition of WTO membership. Upon completion of these bilateral negotiations, the working party finalizes the accession terms in three documents: the working party report, the protocol of accession, and the attached schedules containing the new member's specific liberalization commitments. The final accession terms are then presented to the WTO body for a vote. If two-thirds of the WTO's existing members vote in favor of accession, then the applicant may sign the protocol and join the WTO. (Corvino, 2005). 
have equitable, peaceful high-quality growth, critically speaking, it turns traditional ideas like privatization and free trade on their heads. It is flexible enough that it is barely classifiable as a doctrine. It does not believe in uniform solutions for every situation. It is defined by a ruthless willingness to innovate and experiment, by a lively defense of national borders and interests, and by the increasingly thoughtful accumulation of tools of asymmetric power projection. It is pragmatic and ideological at the same time, a reflection of an ancient Chinese philosophical outlook that makes little distinction between theory and practice. Though it is decidedly post-Deng Xiaoping in structure, the Beijing Consensus still holds tightly to his pragmatic idea that the best path for modernization is one of "groping for stones to cross the river," instead of trying to make one-big, shock-therapy leap".

\subsubsection{BRI (Belt and Road Initiative)}

Another important milestone is represented by the recent China international plan named Belt and Road Initiative (BRI) ${ }^{42}$. The project ${ }^{43}$ was unveiled by Xi Jinping in September and October 2013 during visits to Kazakhstan and Indonesia, and was thereafter promoted by Premier Li Keqiang during state visits to Asia and Europe ${ }^{44}$. It represents the "most ambitious project on the planet" as "the largest ever infrastructure project with close to a trillion dollars being invested across the globe" ${ }^{\$ 5}$ and following the Beijing consensus approach of social harmony and win-win mutual gain it is supposed to be a "symphony of all relevant parties" as Foreign minister Wang Yi described. A new Marshall plan developed in peacetime, and even more, as described by the consultancy McKinse $y^{46}$. "In October 2017, the $19^{\text {th }}$ Communist Party of China (CPC) National Congress was convened successfully. During the conference, BRI was not only established with high priority for future Chinese companies to go out, but also

\footnotetext{
${ }^{42}$ Belt and Road Initiative (BRI) or the Silk Road Economic Belt and the $21^{\text {st }}$-century Maritime Silk Road. Until 2016 the initiative was known in English as the One Belt and One Road Initiative (OBOR). https://en.wikipedia.org/wiki/Belt and Road Initiative. It is also known as Belt and Road (“B \& R").

${ }^{43}$ "Chinese development strategy aiming at the economic integration of Eurasia and the growth of China's Western Provinces, largely through the infrastructural and transportation projects. OBOR's core idea has been to revive ancient land-trade routes in the framework of the Silk Road Economic Belt project (“SREB") supported by the Twenty-first Century Maritime Silk Road (“21MSR”) as proposed by Xi Jinping in Autumn 2013 first in Kazakhstan with regard to the SREB, and subsequently in Indonesia with regard to the 21 MSR. In addition, the OBOR/SREB also includes regional platforms of co-operation, particularly the $16+1$ Group $(\mathrm{G} 16+1)$ gathering

China and Central and Eastern European countries ("CEEs") which was established in April 2012 in Warsaw, that is over a year ahead of the announcement of the OBOR" (Górski et al., 2017). ${ }^{44} \mathrm{Id}$. and "Chronology of China's Belt and Road Initiative". China's State Council. Retrieved 2018-09-23.

${ }^{45}$ https://www.theguardian.com/world/2017/may/12/the-900bn-question-what-is-the-belt-and-road -initiative

${ }^{46}$ Id. "According to the global consultancy McKinsey, the plan has the potential to massively overshadow the US' post-war Marshall reconstruction plan, involving about $65 \%$ of the world's population, one-third of its GDP and helping to move about a quarter of all its goods and services. Some describe Xi's scheme as the biggest development push in history".
} 
incorporated into the CPC Constitution, demonstrating China's determination to promote BRI to achieve regional cooperation, build a new type of international relations and seek win-win outcomes with all countries involved" (EY, 2018).

The main functions of such extraordinary plan are "to provide a new engine for resurrection of the world economy after the international financial crises; to meet the needs of infrastructure; to enhance interconnectivity and exchanges among the countries and regions along the BRI; to help developing countries make economic progress by concentrating on the key sector of infrastructure construction (China's experience); to share the excess products and excess capacity of China with other countries in need; to have more access to energy (oil) and resources" (Wang, 2018).

According to Nin Jizhe, Deputy Director of BRI Construction Leading Office (Aug. 27, 2018) ${ }^{47}$ and recalled by Prof. Wang Chenguang (2018) "The core ideas of the BRI and its principles of wide consultation, joint contribution and shared benefits are incorporated into the UN and other international institutes' documents. 103 countries and international organizations have signed 118 cooperation agreements with China on BRI. In 2017, the first BRI International Cooperation Summit was held in Beijing. The state and government leaders of 29 countries and 1600 representatives from more than 140 countries and more than 80 international organizations attended. Of the 279 outcomes of the Forum, 265 have been completed or converted to work so far, and the remaining 14 are being supervised and promoted, with an implementation rate of 95\%. Joint efforts by Chinese central and local governmental branches for implementing BRI (in Figure 1) and taking other social responsibilities: health, education, environment, sustainability ${ }^{48}$.

As it is likely foreseeable, many concerns and worries are coupled with International enthusiasm surrounding such a majestic project. Some of the most important issues to face and questions to answer are discussed by (Górski et al., 2017):

"What are the potential issues with the legal form/structure, ownership, capitalization, decision-making process, and governance of China-led institutions meant to finance OBOR-related projects, including the Asian Infrastructure Investment Bank (“AIIB"), the New Development Bank ("NDB"), the New Silk Road Fund ("NSRF"), and the China Investment Corporation ("CIC")? What are the challenges to the OBOR transit routes arising out of inter-regional and international rivalries? How do these institutions compare with the solutions commonly accepted in the existing system of development aid (under the World Bank's leadership) and by sovereign

${ }^{47}$ https://news.cgtn.com/news/3d3d774d796b7a4e79457a6333566d54/index.html.

48"15 Ministries such as MOFCOM, National Health Commission, National Customs Office, NDRC, MOF, Bank of China, has plans for promoting health for BRI; These programs have projects with detailed plans and responsible agencies". 


\section{The B\&R connectivity updates}

\section{Policy coordination}

- 86 countries, regions and international organizations have signed 100 cooperation agreements with China on jointly building the $\mathrm{B} \& \mathrm{R} 8$

- By October 2017, China has Signed bilateral tax treaties, agreements and arrangements with 106 countries and regions, within which 54 countries are along the B\&R
Facilities connectivity

During 2017, 3,600 ChinaEurope

freight trains offered their services, surpassing the total number of combined runs from the previous 6 years 14

- In 2017, China has signed Contracted projects worth of US $\$ 144.3$ billion with 61 countries along the B\&R, accounting for $54 \%$ of total value and increased by $15 \%$ YoY

\section{Financial integration}

- Chinese enterprises invested US\$14.4 billion into 59 countries along the route in 2017 , accounting for $12 \%$ of the total, up 3.5 percentage points YoY

- AllB has approved 24 projects and issued nearly US $\$ 4.2$ billion of loans since its opening in 20168

In 2017, China overseas M\&As along the B\&R achieved a record high of US $\$ 48.2$ billion, up $81 \%$ YoY

- The Silk Road Fund has committed nearly US $\$ 7$ billion to 17 projects since its operation 3 years ago

Figure 1. EY (2018) sum-up of BRI plans.

\section{Unimpeded trade}

In 2017, China's imports and exports with B\&R countries recorded a total value of RMB7.37 trillion, up $17.8 \%$ YoY 15

- China is developing 75 overseas economic and trade cooperation zones along the B\&R.

Accumulative investment has exceeded US $\$ 27$ billion, attracting nearly 3,500 companies to move in. This also has contributed US $\$ 2.2$ billion taxes to the local countries and has created nearly 210,000 jobs

\section{People-to-people bond}

China reached agreement with 24 B\&R countries on mutual academic degree recognition

The "Silk Road Scholarship" from the Chinese Government offers no less than 3,000 new scholarships each year for students from B\&R countries

wealth funds of other countries? Where do Chinese state-owned commercial banks stand in this landscape? What are the distinctive features (compared with Western development-aid institutions), if any, of conditions of financing by OBOR-related institutions, such as governing law and terms and conditions of loans or procurement-rules related to financed projects? How is sustainability integrated into operations of such institutions including labor right, social rights, protection against expropriations, protection of indigenous peoples? How does it compare with existing development aid institutions? Development on a specific AIIB framework/institution to handle investment disputes? What are the potential issues with the settlement of disputes, including disputes between 1) stakeholders in financing institutions, 2) financing institutions and borrowers, 3) foreign contractors/suppliers/ service-providers and borrower's procuring agencies?"

In addition, as any business activity, the BRI project incorporates relevant risks, i.e. Political Risks and Projects Cancellation or Suspension; Economic Risks: Financial Risks; Corruption and Good Practice; Legal and Regulatory Risks; Environmental Risks; Labor Issues; International Situation; Changes of 
the Partners' Mind as the Market Fluctuates ${ }^{49}$ (Wang, 2018). In addition to those generic risks, common to all countries and participants, some specific must be considered, particularly "legislative or regulatory defects and loopholes" (Wang, 2018) and, especially, in China the high-exposure of the Chinese banking sys$\mathrm{tem}^{50}$, which is already considered fragile for other reasons, some of which will be discussed below. Given the enormous scope and scale of the initiative, and the multiplicity of players involved, it is clear that if something goes wrong, it might have spread around negative consequences. This might be the direct result of the so-called "soft budget constraints ${ }^{51}$ ", i.e. "The news highlights the risk that the state could amass hundreds of billions of dollars in nonperforming loans if the projects fail" says Xu Chenggang, professor of economics at Cheung Kong Graduate School of Business in Beijing and he adds that

"the impact could be damaging not just for China, but for the global finan-

cial system. These loans are being extended to governments in risky countries

\begin{abstract}
49"Political Risks and Projects Cancellation or Suspension (not rare): Change of the government; Change of policies;
Nationalization or Privatization; Expropriation plus creeping expropriations by discriminatory taxes, price controls or license issuance, etc.; Cancellation of the project by Foreign Investment Review, etc.; Prohibition of Entry into the Market. Economic risks: Inflation risk and commodity price risk; Cash flow risk (long-term and steady cash flow required); construction risks, such as delay, various accidents; Tax policy risk; Operational risks, such as maintenance risk, quality staff risk, cost and schedule overruns, traffic and energy supply risks; Partners' risks e.g. bankruptcy or closure, and Emerging market risks (oversupply or price cap). Financial risk: In the most recent years, the negative public saving-investment balances have contributed to higher government debt-to-GDP ratios. Foreign exchange control or capital control regimes; Currency depreciation or appreciation; Debt burden and financial risks (For instance, the $\$ 15$ billion China-Uzbekistan investment transaction agreed by both parties is almost equal to $25 \%$ of Uzbekistan's GDP, the $\$ 24$ billion China-Bangladesh agreement signed in October 2016 is around 20\% of Bangladesh's GDP ); Credit Enhancement against Credit Risks or Debt Default by the host; MIGA and other Guarantee agencies; Investors' financial risks; Prevention of Black Swan and Gray Rhino. Corruption is a serious disease in developing countries; The OECD's survey indicates that about $40 \%$ foreign bribery cases occurred in three sectors: $15 \%$ in construction, $15 \%$ in transportation and storage, and $10 \%$ in information and communication; To Set up good professional practice ethics; To promote anti-corruption legal mechanisms, such as US FCPA; To ask for legal documents for every business dealings; To fulfill corporate social responsibilities. Legal, Regulatory and Policy Risks: Legislative or regulatory defects or loopholes; Sudden changes of existing laws;

Fair treatment of investors; Delays in implementing rules; Difficulties in acquiring land, property transfer, license issuance, or infrastructure building; Lack of effective dispute resolution mechanisms (such as BRI arbitration institutes) and enforcement mechanisms; Bad economic policy: Crowd in FDI \& crowd out Domestic Investment. Environmental Risks: Particularly for infrastructure construction, the risks include but not limited to pollution prevention and abatement, demolition and relocation, biodiversity conservation and ecological protection, indigenous people and cultural heritage; Pay particular attention to environmental protection; The case of the Myitsone Dam in Myanmar (The hydropower project is USD 3.6 billion. One partner is subject to sanction due to drug dealing. Myanmar would get 10\% electricity for free in 50 concessional periods and the full ownership through build-operate-transfer (BOT) 50 years later. This project, however, was suspended in mid-2012 by Myanmar's former military government, due to public opposition and environmental issues.). Labor Issues:

Lack of skilled and experienced workers; On job training; Respect for local staff; Good payments and welfare package; Safe and healthy working environment; Transparent rules of working place; Sufficient consultation and quick and fair dispute resolution. International Situation: Regional war; Pressure from other powerfuls resulting in cancellation or market closure; International media distortion or prejudice; Geopolitical considerations. Changes of the Partners or Government's Mind as the Market Fluctuates: Market changes and partner's mind changes;

Enticement for more profits or opportunities; Pressure from outside; Business goes down and other hardships; The local or national economy goes down; Changes of regional or national development scheme; Host country's smart economic policies for good use of DFI and BOT, BOOT \& DBFO of infrastructure (PPP); Policy changes of the relation between proactive but clean government (necessary) and the market" (Wang Chenguang, 2018).

50“'Some are worried that the project could create a problem for China's banking sector-which would be a problem for the world". In particular "China Construction Bank, the country's second-largest bank by assets, has been conducting road shows to raise at least 100 billion yuan ( $\$ 15$ billion) from on- and offshore investors, sources familiar with the matter told Reuters. Bank of China, Industrial and Commercial Bank of China, and Agricultural Bank of China are also said to be raising tens of billions of dollars, though none of the banks responded to Reuters' request for comment". https://www.cnbc.com/2017/08/24/chinas-belt-and-road-initiative-could-be-the-next-risk-to-the-global-financial-system.html.

${ }^{51} \mathrm{Id}$. "Soft budget constraints refer to the idea that state-owned firms will not be allowed to go bankrupt if they go insolvent because the state has vested interests in keeping them afloat. A country with high soft budget constraints and a large number of insolvent firms may then struggle for financing, which could have global financial implications".
\end{abstract}


to fund risky infrastructure projects. If the projects were launched by private firms we wouldn't have to worry because they would know they had to bear the consequences. But here we are talking about government-to-government lending and, ultimately, intergovernmental relations".

Once again the discussion about performance and expected returns of business is at stake. As usual, much of the economic engine in China and in this project is driven by State-owned enterprises, it would relevant to analyze the corporate structure of the companies involved, starting from their set goals to the corporate governance structure in order to assess whether they are likely to compete and perform properly. Xu Chenggang argues that "for a country like China, where state-ownership has historically been high, this is a matter of particular concern. It took decades of economic reforms and loss-making firms before it succeeded in what he termed a process of "quiet privatization" at the turn of the $21^{\text {st }}$ century. However, the process has lost momentum over the past ten years, and the state remains burdened with issues of overcapacity and myriad "zombie firms," especially within the metals and construction and materials sectors ${ }^{52}$. This paper's frame might then perhaps usefully be applied to such companies as well.

\section{Conclusions}

\subsection{Findings}

The Chinese business model represents a unicum in the world. And the Chinese corporate law frame follows the particular idea of society and economy the country developed over time. The Socialism with Chinese characteristics is today a combination of social goals orientation and spin to compete efficiently and effectively in the international arena. While in many Western countries, Milton Friedman is being misinterpreted to lead companies towards pure profit maximization, at least in China such an approach has never been embedded in corporate law. Actually, neither statutes nor case law ever confirmed the profit maximization orientation in any country. And it is not been widely adopted in the company's Articles of Associations. However in some countries (of further analysis) it became the polar stellar of business practice while in China is definitely not.

The Chinese corporate law and corporate governance model is particularly interesting. In this paper we highlighted how the globalization phenomenon and in particular the advances in the Chinese corporate law frame is leading to new company goal setting and Corporate Governance rules.

WTO accession acted as a boost for economic and legal reform by locking the road to reforms and making it irrevocable. In addition to causing liberalization of China's trading system, Chinese leadership sponsored through WTO accession the commencement of wide and profound legal reform, which will probably

${ }^{52}$ Id. 
result in weakened control of the Communist Party on both the economic trends and on the growing civil society. Despite that, the Chinese Constitution of the CPC still recognizes the central role of Party organizations to "keep in mind the big picture, ensure the implementation of Party policies". This represents an uniqum in the economic arena. It has shown its efficacy to develop corporations that can be competitive and successful in the international markets and which, at the same time, can take good care of the principles of the Socialism with Chinese characteristics. The BRI is an example of how such an approach can be spread overseas and make co-operations with foreign entities effective.

This research paper is deemed to have contributed to give clarity to such phenomen. By analyzing the framework and principles developments of the Chinese Go-Global plans, the article aims at providing insight and non-obvious considerations of the domestic pattern and its international implications. The modernization process, with Chinese characteristics, is actually a multifacet and long committing plan to put in place deep reforms which led to many achievements but also faced many difficulties. How to reconcile the National principles and social goals attention with the market forces has been the polar star of regulations and law implementations. As pointed out here this creates an uniquum which success worth analyzing.

\subsection{Future Research}

Given the open questions, interesting topics for future research to be explored may include the impact of the frames of the Chinese Corporate law and Corporate Governance on international standard; the convergenges a commingle of Western and Eastern approaches; the auspicable positive implications on stakeholders, including the overcoming of local worries and concerns for targets of Chinese M\&A; the consistency of future developments with the approach described here?

Last but not least, it will be important to monitor how the Corporate Governance frame develops in the future if strategic interests and management goals start to diverge?

In general, it will be interesting to observe the advances and future implications the BRI will bring to the Chinese national corporate environment and its international impact.

All the above can be interesting topics for further research.

\section{Conflicts of Interest}

The author declares no conflicts of interest regarding the publication of this paper.

\section{References}

Art, R. C., \& Gu, M. K. (1995). China Incorporated: The First Corporation Law of the People's Republic of China. Yale Journal of International Law, 20, 273-308. 
Bakan, J. (2003). The Corporation: The Pathological Pursuit of Profit and Power. New York, London, Toronto, Sydney: Free Press.

Blair, M. (1995). Ownership and Control: Rethinking Corporate Governance for the Twenty-First Century. Brookings.

Blair, M. (2012). The Four Functions of Corporate Personhood. Public Law \& Legal Theory, Law \& Economics, Working Paper Number 12-15.

Blair, M., \& Stout, L. A. (1999). A Team Production Theory of Corporate Law. Virginia Law Review, 85, 247-328. https://doi.org/10.2307/1073662

Caragliano, D. (2009). Administrative Governance as Corporate Governance: A Partial Explanation for the Growth of China's Stock Markets Explanation for the Growth of China's Stock Markets. Michigan Journal of International Law, 30.

Fang, L. F. (1995). China's Corporatization Experiment. Duke Journal of Comparative and International Law.

Freeman, E. R. (1984). Strategic Management-A Stakeholder Approach. Part of Pitman series in Business and Public Policy.

Górski, J., Chaisse, J., Chi, M., Ahmad, M., \& Cheng, T. (2017). One Belt One Road Initiative (“OBOR”): Editorial. Transnational Dispute Management (TDM).

https://www.transnational-dispute-management.com/article.asp?key=2469

Hansmann, H. (2006). How Close Is the End of History? The Journal of Corporation Law, $31,745-751$.

Hansmann, H., \& Kraakman, R. (1997). The End of Corporate Law, for Corporate Law, Georgetown Law Review, 2001. (Originally prepared for a conference entitled "Are Corporate Governance Systems Converging?", held at Columbia Law School on December 5)

Hansmann, H., \& Kraakman, R. (2012). Reflections on the End of History for Corporate Law, 2011. (Forthcoming in Abdul Rasheed and Toru Yoshikawa, Eds., Convergence of Corporate Governance: Promise and Prospects, Palgrave-MacMillan)

Kirby, W. C. (1995). China Unincorporated: Company Law and Business Enterprise in Twentieth-Century China. The Journal of Asian Studies, 54, 43-63. https://doi.org/10.2307/2058950

Mahony, T. (2015). Foreign Investment Law in China: Regulation, Practice and Context. Beijing: Tsinghua University Press.

Ramo, J. C. (2014). The Beijing Consensus. The Foreign Policy Centre.

Stout, L. A. (2012). The Shareholder Value Myth: How Putting Shareholders First Harms Investors, Corporations, and the Public. San Francisco, CA: Berrett-Koehler Publishers.

Tomasic, R. (2010). Looking at Corporate Governance in China's Large Companies: Is the Glass Half Full or Half Empty? In G. H. Yu (Ed.), The Development of the Chinese Legal System Change and Challenges. New York: Routledge.

Tse Caleb, H., Yu, L. H., \& Tse, D. K. (2012). Understanding China's State Capitalism through Its SOEs: The Effect of Globalization and State Ownership in the Pursuit of Economic and Social Goals.

Ventoruzzo, M. (2007). Cross-Border Mergers, Change of Applicable Corporate Laws and Protection of Dissenting Shareholders: Withdrawal Rights under Italian Law. Penn State Legal Studies Research; Bocconi Legal Studies Research Paper No. 16; European Company and Financial Law Review (ECFR). https://ssrn.com/abstract=960579

Ventoruzzo, M., Conac, P.-H., Goto, G., Mock, S., Notari, M., \& Reiseberg, A. (2015). Comparative Corporate Law. American Casebook Series. 
Wang, C. G. (2018). Legal Issues of BRI. PPT Document, for the BRI Training Program Only, September.

Xi, J. P. (2014). The Governance of China. Beijing: Foreign Languages Press.

Yu, G. G. (2010). The Development of the Chinese Legal System: Change and Challenges. London: Routledge. https://doi.org/10.4324/9780203837757

Zhang, L. (2014). Corporate Governance of Chinese State-Controlled Listed Companies: A Revisit through the Lens of Venture Capital. European Business Organization Law Review, 15, 107-139. https://doi.org/10.1017/S1566752914001050

Zhang, X. C. (2003). New Landscape of Foreign Mergers and Acquisitions in China after Its WTO Accession. Journal of Chinese and Comparative Law, No. 2, 229-255. 


\section{Appendix}

\section{Other sources}

ACGA China CG Report 2018, Awakening Governance, The Evolution of corporate governance in China, 2018.

China goes abroad ( $7^{\text {th }}$ edition), Belt and Road - exploring a blueprint for steady growth in overseas investment, EY Greater China B\&R Taskforce, April 2018

\section{WEBSITE}

http://www.oecd.org/corporate/principles-corporate-governance.htm http://www.oecd.org/corporate/

http://english.china.com/zh cn/business/faq/11024764/20041015/11917309.html http://english.mofcom.gov.cn/aarticle/lawsdata/chineselaw/200301/20030100062 $\underline{858 . h t m l}$

http://english.mofcom.gov.cn/aarticle/lawsdata/chineselaw/200301/20030100062 868.html

http://english.peopledaily.com.cn/200210/03/eng20021003 104347.shtml http://news.bbc.co.uk/1/hi/business/1734229.stm http://web.tiscali.it/qigong/italiano/principi\%20teorici.htm http://www.1upinfo.com/country-guide-study/china/china238.html http://www.beijing.gov.cn/ http://www.bis.org/bcbs http://www.bis.org/press/p981027.htm\#pgtop http://www.bis.org/publ/bcbsc113.pdf http://www.chinabusinessreview.com http://www.chinadaily.com.cn/ http://www.cmbc.com.cn/cmbcen/article/20030610/20030610001519 1.xml http://www.cmbc.com.cn/nianbao/2001report4.doc

http://www.corriereasia.com

http://www.drcnet.com.cn http://www.ebeijing.gov.cn/default.htm http://www.ft.com/home/asia

(Francesco Sisci)

http://www.nbr.org

http://www.pbc.gov.cn

http://www.retailindustry.about.com

http://www.shanghai.gov.cn/

http://www.shanghai.it/

http://www.standardandpoors.com

http://www.state.gov/r/pa/ei/bgn/

http://www.unctad.org/en/docs//wir2002_en.pdf

http://www.wto.org

http://www.wto.org/english/news e/pres01 e/pr249 e.htm

http://www.wto.org/english/tratop e/tpr e/tpr e.htm

http://www.wuxi.gov.cn/ (Chinese) 